\title{
SPATIAL DISTRIBUTION OF SOME CHEMICAL CHARACTERISTICS OF AN ACID SULFATE SOIL- AFFECTED BRACKISHWATER PONDS IN THE COASTAL AREA OF LUWU REGENCY SOUTH SULAWESI PROVINCE
}

\author{
Erna Ratnawati\# and Akhmad Mustafa \\ Research and Development Institute for Coastal Aquaculture, Maros
}

(Received 2 January 2014; Accepted 2 May 2014)

\begin{abstract}
Spatial distribution of brackishwater pond soil has important role in the system of bioenvironment including brackishwater pond environment. This research was aimed to determine the spatial distribution of some chemical characteristics of an acid sulfate soil- affected brackishwater pond in coastal area of Luwu Regency South Sulawesi Province, Indonesia. ALOS AVNIR- 2 images (acquisition 16 May 2008, 16 October 2008, 17 September 2009) were integrated with Indonesian Topographic maps to obtain base map. Sampling soil points were determined by simple random sampling in 104 points for two different soil depths i.e. $0-0.2 \mathrm{~m}$ and $0.5-0.7 \mathrm{~m}$. A total of 18 soil chemical characteristics was measured in the field and analyzed in the laboratory. Geostatistic using kriging method in the ArcGIS 9.3 software was used to interpolate the data. The results of this study indicated that in general pond soil chemical characteristics in Luwu Regency could be categorized with high variability or relatively heterogenic with the value of variation coefficient more than $36 \%$ The soil characteristics that explain acidity had shown similar pattern in spatial distribution as well as other soil characteristics with soil nutrient. The high value of $\mathrm{pH}$ and low value of $\mathrm{PO}_{4}$ were generally found in the northern part of Luwu Regency, including East Lamasi, East Walenrang, Bua, and Ponrang Subdistricts. It is recommended that soil management in brackishwater ponds of Luwu Regency could be based on soil chemical characteristics so its could improve the production through minimizing the input, increasing carrying capacity, and avoiding environmental degradation.
\end{abstract}

KEYWORDS: spatial analysis, soil, brackishwater pond, coastal area, Luwu Regency

\section{INTRODUCTION}

Ministry of Marine Affairs and Fisheries of the Republic of Indonesia has programs focused on minapolitan, industrialization, and blue economic to increase fisheries production, especially aquaculture production. Aquaculture is currently implemented in Indonesia including marine culture, brackishwater pond, freshwater pond, paddy fields, and inland open waters. Potency land for brackishwater ponds reached $2,963,717$ ha with the utilization only about $682,857 \mathrm{ha}$; and the production of $1,737,260$ tonnes (MMAF, 2011).

Until 2008, the gross area of brackishwater ponds in the east coast of South Sulawesi Province reached 50,131 ha (Anonymous, 2009).

\# Corresponding author. Research and Development Institute for Coastal Aquaculture Jl. Makmur Dg. Sitakka No. 129, Maros 90512, Sulawesi Selatan, Indonesia. Tel.: +62 411371544 E-mail: ernaratnawati60@yahoo.co.id 
Brackishwater ponds are distributed in East Luwu, North Luwu, Luwu, Wajo, Bone, and Sinjai Regencies as well as in Palopo City with the area of 11,$397 ; 6,367 ; 6,889 ; 12,000 ; 11,633$; 714; and 1,131 ha; respectively. Brackishwater ponds in Luwu Regency mainly used to produce tiger shrimp (Penaeus monodon), speckled shrimp (Metapenaeus monoceros), whiteleg shrimp (Litopenaeus vannamei), seaweed (Gracilaria verrucosa), milkfish (Chanos chanos), and other fish such as tilapia (Oreochromis niloticus).

One of the environmental factors that affect brackishwater ponds productivity is soil quality. Soil quality is a major factor of production in aquaculture because it can affect water quality, biological, and engineering processes of brackishwater ponds (Sammut, 1999). Therefore, generally, soil quality has to be considered in land suitability evaluation for brackishwater ponds (Treece, 2000; Salam et al., 2003; Giap et al., 2005; Karthik et al., 2005; Mustafa et al., 2011). One type of soil which is common in brackishwater ponds of coastal area in Indonesia, including Luwu Regency is acid sulfate soil (Mustafa, 2007). Acid sulfate soil is the common name given to soil or sediment containing iron sulfides or pyrite (Dent, 1986; Sammut \& Lines- Kelly, 2000; Lin et al., 2004; Schaetzl \& Anderson, 2005). Chemical characteristics of the soil need much more attention than physical and biological characteristics of the soil and a lot of acid sulfate soil chemical characteristics which is a typical characteristic of the acid sulfate soil.

Spatial distribution of soil types is controlled by a set of environmental factors such as climate, organisms, parent material, and topography as well as time and space (Barthold et al., 2013); in which changes in the environmental factors will change the spatial distribution of soil types. Identification of the spatial distribution of soil characteristics has an important role in many bio- environmental systems (Zuo et al., 2008; Dong et al., 2009; Akbarzadeh \&Taghizadeh- Mehrjardi, 2010; Zare- Mehrjardi et al., 2010; Yu et al., 2011). Knowledge of spatial variability on soil characteristics and soil intercharacteristic relationship is important for the evaluation of soil management practices (Huang et al., 2001; Saadi \& AthanasopoulosZekkos, 2013), and increases the sustainability of land cover/land use (Liu et al., 2006). Variability is one of the essential characteristics of the soil quality and the same ecosystem soil quality may show noticeable spatial varia- tions (Robinson \& Metternicht, 2006). These variations are mainly arise from the factors and processes of pedogenesis and land cover/ land use (Tuzinsky, 1990; Ersahin, 2003; Martin et al., 2011; Beguería et al., 2013) as well as land management practices (Pan Gozalez et al., 2000; Anuar et al., 2008). With classical statistics that take into account the data of land as free data, the implementation often produces unrealistic results (Zare- Mehrjardi et al., 2010). In addition, contrary to the assumption that when used classical statistics is that the soil characteristics on a landscape are not distributed randomly (not just random variability but also not correlated to the spatial location) (Essington, 2004). Natural soil characteristics can vary continuously in time and space, and for such conditions is very difficult if it is possible to measure the quality of the soil at any point in the field (Madyaka, 2008). Spatial variation in soil characteristics are so complex that no description can be resolved, so the prediction is certain or uncertain (Aberegg et al. 2009). Geostatistics can be used to characterize and quantify the spatial variability of soil characteristics, rationally interpolate, and estimate or predict the difference of the interpolated values (Lin et al., 2001; Essington, 2004). Therefore, geostatistical method was applied in this study to better understand the spatial distribution of some chemical characteristics of acid sulfate soils in coastal area of Luwu Regency South Sulawesi Province. Results of this study could be used as a basic for determining soil management.

\section{MATERIALS AND METHODS}

The research was conducted in July 2010 in Luwu Regency South Sulawesi Province, Indonesia. Research sites were distributed in 11 coastal subdistricts, namely: East Lamasi, East Walenrang, Bua, Ponrang, South Ponrang, Kamanre, North Belopa, Belopa, Suli, Larompong, and South Larompong (Figure 1). The research was initiated in the form of discussions with staff of Marine and Fisheries Office of Luwu Regency in Belopa in order to obtain general information about brackishwater ponds in coastal area of Luwu.

\section{Data Collection}

\section{Primary Data}

Soil chemical characteristics were the primary data used in this study. Points of measurement and soil sampling were randomly 


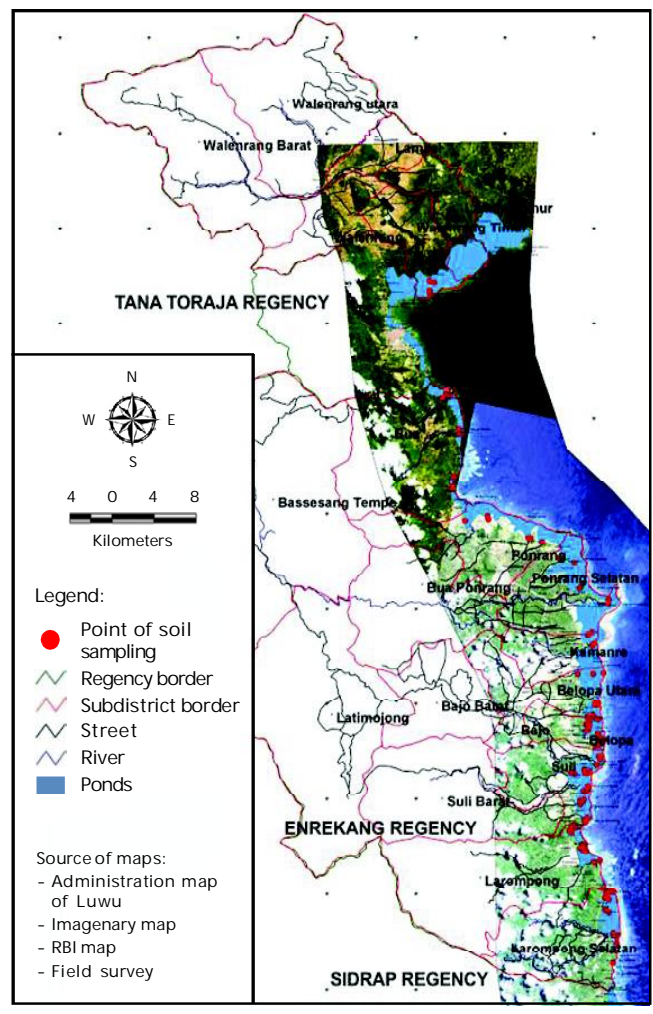

Figure 1. Points of soil sampling in brackishwater ponds of Luwu Regency South Sulawesi Province

determined at 104 measurement points, and soil sampling following the instructions from Hazelton \& Murphy (2009). Soil quality variables directly measured in the field were $\mathrm{pH}_{\mathrm{F}}($ soil $\mathrm{pH}$ measured in the field) with a pH- meter (Ahern \& Rayment, 1998); $\mathrm{pH}_{\mathrm{Fox}}$ (soil $\mathrm{pH}$ was measured in the field after oxidized with hydrogen peroxide $\left(\mathrm{H}_{2} \mathrm{O}_{2}\right) 30 \%$ with $\mathrm{pH}$ - meter (Ahern \& Rayment, 1998); and redox potential with redox- meter. Soil samples were taken at two soil depths from the soil surface, i.e. 0.0-0.2 m and 0.5- $0.7 \mathrm{~m}$. For analyzing other soil quality variables, soil sample was immediately collected in plastic bag and then stored in a cool box containing ice; because the soil samples were classified as acid sulfate soil. Left over fresh herbs, pebbles, shells, other debris, and garbage were taken out manually by hand. Soil samples were oven- dried at $80^{\circ} \mathrm{C}-85^{\circ} \mathrm{C}$ for 48 hours (Ahern \& Blunde, 1998). Once dried, pulverized soil samples were ground on porcelain mortar and sieved with sieve having 2.0 $\mathrm{mm}$ and $5.0 \mathrm{~mm}$ mesh size and then analyzed in the Soil Laboratory of Research Institute for Coastal Aquaculture (RICA) in Maros, South Sulawesi Province. Soil quality analyzed in the laboratory include $\mathrm{pH}_{\mathrm{KCl}}$ ( $\mathrm{pH}$ of $\mathrm{KCl}$ extract) (McElnea \& Ahern, 2004a), $\mathrm{pH}_{\mathrm{ox}}$ (McElnea \& Ahern, 2004b), $\mathrm{S}_{\mathrm{p}}$ (sulfur peroxide) (McElnea \& Ahern, 2004C), $\mathrm{S}_{\mathrm{KCl}}$ (sulfur is extracted by $\mathrm{KCl}$ ) (McElnea \& Ahern, 2004d), $S_{\text {POS }}\left(S_{P}-S_{K C I}\right)$ (Ahern \&McElnea, 2004), TPA (Titratable Peroxide Acidity or previously known as Total Potential Acidity) (McElnea \& Ahern, 2004b), TAA (Titratable Actual Acidity or previously known as Total Actual Acidity) (McElnea \& Ahern, 2004a), TSA (Titratable Sulfidic Acidity or previously known as Total Sulfidic Acidity) (TPA - TAA) (McElnea \& Ahern, 2004b), pyrite (Ahern et al., 1998a; 1998b), organic carbon by Walkley and Black method (Sulaiman et al., 2005), total $\mathrm{N}$ by Kjedhal method (Sulaiman et al., 2005), $\mathrm{PO}_{4}$ by Bray 1 or Olsen method (depending on soil pH) (Sulaiman et al., 2005), Fe and Al with a spectrophotometer (Menon, 1973).

\section{Secondary Data}

Secondary data were collected by searching various reports, literatures, research on the results of various related agencies, satellite imagery, and maps. ALOS (Advanced Land Observing Satellite) AVNIR- 2 (The Advanced Visible and Near Infrared Radiometer type 2) acquired on 16 May 2008 (2 scenes), 16 October 2008 (1 scene), and 17 September 2009 (1 scene) were used in this study. Indonesia Topographic maps of 1:50,000 scale were collected from Indonesian Geospatial Agency such as sheets number 2113- 14 (Masamba Sheet), 2113- 12 (Amassangan Sheet), 2113- 11 (Palopo Sheet), 2112- 44 (Padangsappa Sheet), 2112-42 (Belopa Sheet), and 2112-14 (Larompong Sheet), and map of Luwu Administration.

\section{Data Analysis}

Maps of land cover/land use classification were acquired from the image of ALOSAVNIR- 2 by using ER Mapper 7.1. The ALOS AVNIR- 2 images were integrated with Indonesia Topographic maps in order to obtain the base map. Other spatial information derived from primary and secondary data were also integrated with the map of land cover/land use. Data of variable soil characteristics from the same soil depth were analyzed by classical statistical methods to obtain minimum, maximum, average, standard deviation, coefficient of varia- 
Indonesian Aquaculture Journal Vol. 9 No. 1, 2014

tion, curtosis, and skewness based on the instructions from Sokal \& Rohlf (1981). Kriging method (Mulla \& McBratney, 1999; Essington, 2004; Lin, 2008; Saadi \& AthanasopoulosZekkos, 2013) in ArcGIS 9.3 software was used in the interpolation of the existing soil data at 0- $0.2 \mathrm{~m}$ soil depth.

\section{RESULTS AND DISCUSSION}

Soil types found in brackishwater ponds of Luwu Regency were dominated by acid sulfate soil and acid sulfate soil associated with peat soils. Based on soil taxonomy (Soil Survey Staff, 2001), soil in the coastal area of Luwu is classified as sulfaquent, hydraquent, and sulfihemits for great groups. Sulfaquentis characterized by aquents that has sulfidic materials or pyrite up to $0.5 \mathrm{~m}$ from soil surface and is included as potential acid sulfate soil. Hydraquent is characterized by a depth of $1.0 \mathrm{~m}$ from the soil surface and has sulfidic materials or sulfiric layer at a depth of 0 to $0.15 \mathrm{~m}$ or more and in addition it has $\mathrm{pH}$ of 3.5-4.0. Hydraquent and sulfaquent classified into entisol while in Soil Classification System of Soil Research Centre they are classified into
Alluvium. Acid sulfate soil is not only found in mineral soil, but also in organic soil, including acid sulfate soil. In Luwu Regency was classified as sulfihemits. Sulfihemits is characterized by the presence of sulfidic materials up to 1.0 $\mathrm{m}$ of the surface that does not oxidize and does not have a sulfuric horizon at a depth of $0.5 \mathrm{~m}$ from the surface and is also classified as potentially acid sulfate soil. In the category of Major Soil Group, sulfihemits is histosol or in Soil Classification System of Soil Research Centre it is classified into organosol.

Based on the coefficient of curtosis, most of the data on the chemical characteristics of brackishwater ponds soil of Luwu Regency were distributed relatively platykurtic (flat) with coefficient of curtosis less than 3 , both in $0-0.2 \mathrm{~m}$ soil depth (Table 1 ) and $0.5-0.7 \mathrm{~m}$ soil depth (Table 2). Tables 1 and 2 also showed that most data of soil characteristics in Luwu Regency were skewed to the right with skewness coefficient less than 2, and in general data of soil characteristics has also indicated positive skewness. This indicates that data in each soil characteristics of brackishwater pond in Luwu Regency have relatively equal distri-

Table 1. Chemical characteristics of brackishwater ponds soil in 0- $0.2 \mathrm{~m}$ soil depth in coastal area of Luwu Regency South Sulawesi Province $(n=104)$

\begin{tabular}{|c|c|c|c|c|c|c|c|}
\hline Variables & Minimum & Maximum & Average & $\begin{array}{l}\text { Standard } \\
\text { deviation }\end{array}$ & $\begin{array}{l}\text { Coefficient } \\
\text { of variation }\end{array}$ & Curtosis & Skewness \\
\hline Redox potential (mV) & -518 & 349 & -272.3 & 110,458 & 40,558 & 8,918 & 1,962 \\
\hline $\mathrm{pH}_{\mathrm{F}}$ & 5.31 & 8.26 & 6.89 & 0.376 & 5,454 & 3,346 & -0.351 \\
\hline $\mathrm{pH}_{\mathrm{FOX}}$ & 1.22 & 6.01 & 2.41 & 1,266 & 52,524 & 1,080 & 1,522 \\
\hline $\mathrm{pH}_{\mathrm{F}}-\mathrm{pH}_{\mathrm{FOX}}$ & 0.99 & 6.15 & 4.48 & 1,246 & 27,803 & 0.940 & $-1,421$ \\
\hline $\mathrm{pH}_{\mathrm{KCl}}$ & 1.28 & 7.75 & 5.56 & 1,359 & 24,451 & 0.550 & $-1,051$ \\
\hline $\mathrm{pH}_{\mathrm{Ox}}$ & 0.90 & 6.79 & 2.25 & 0.875 & 38,802 & 7,008 & 2,088 \\
\hline $\mathrm{S}_{\mathrm{KCl}}(\%)$ & 0.07 & 1.85 & 0.54 & 0.411 & 76,340 & 1,526 & 1,459 \\
\hline $\mathrm{S}_{\mathrm{p}}(\%)$ & 0.35 & 4.64 & 2.07 & 1,044 & 50,368 & -0.445 & 0.401 \\
\hline $\mathrm{S}_{\mathrm{POS}}(\%$ & 0.13 & 3.56 & 1.54 & 0.797 & 51,928 & -0.601 & 0.210 \\
\hline TPA (mole H/ tonne) & 0.00 & $3,453.00$ & 556.73 & 594,623 & 106,807 & 5,429 & 2,093 \\
\hline TAA (mole $\mathrm{H}^{+} /$tonne) & 0.00 & 223.00 & 6.57 & 24,936 & 379,692 & 56,754 & 6,981 \\
\hline TSA (mole $\mathrm{H}^{+} /$tonne) & 0.00 & $3,418.00$ & 550.16 & 582,900 & 105,951 & 5,588 & 2,100 \\
\hline Pyrite $(\%)$ & 0.00 & 15.26 & 2.46 & 2,602 & 105,951 & 5,588 & 2,100 \\
\hline Total N (\%) & 0.04 & 1.63 & 0.44 & 0.304 & 69,821 & 4,065 & 1,898 \\
\hline $\mathrm{PO}_{4}(\mathrm{ppm})$ & 2.77 & 113.57 & 20.65 & 16,475 & 79,793 & 9,854 & 2,580 \\
\hline Organic matter $(\%)$ & 1.17 & 27.87 & 8.70 & 6,496 & 74,636 & 0.955 & 1,250 \\
\hline $\mathrm{Fe}(\mathrm{mg} / \mathrm{L})$ & 114.00 & $5,085.00$ & $3,765.77$ & $1,465.670$ & 38,921 & 0.675 & $-1,423$ \\
\hline $\mathrm{Al}(\mathrm{mg} / \mathrm{L})$ & 0.01 & 777.00 & 348.46 & 126,411 & 36,277 & 1,845 & 0.065 \\
\hline
\end{tabular}


Spatial distribution of some chemical characteristics ... (Erna Ratnawati)

Table 2. Chemical characteristics of brackishwater ponds soil in 0.5- $0.7 \mathrm{~m}$ soil depth in coastal area of Luwu Regency South Sulawesi Province $(n=104)$

\begin{tabular}{|c|c|c|c|c|c|c|c|}
\hline Variables & Minimum & Maximum & Average & $\begin{array}{l}\text { Standard } \\
\text { deviation }\end{array}$ & $\begin{array}{l}\text { Coefficient } \\
\text { of variation }\end{array}$ & Curtosis & Skewness \\
\hline Redox potential (mV) & -445 & 387 & -289.8 & 107.50 & 37,101 & 14,171 & 2,806 \\
\hline $\mathrm{pH}_{\mathrm{F}}$ & 6.23 & 7.65 & 6.76 & 0.263 & 3,889 & 0.464 & 0.507 \\
\hline $\mathrm{pH}_{\mathrm{fOX}}$ & 0.95 & 4.34 & 1.72 & 0.476 & 27,622 & 9,725 & 2,523 \\
\hline $\mathrm{pH}_{\mathrm{F}}-\mathrm{pH}_{\mathrm{FOX}}$ & 2.09 & 6.33 & 5.04 & 0.545 & 10,806 & 8,412 & $-1,937$ \\
\hline $\mathrm{pH}_{\mathrm{KCl}}$ & 1.49 & 7.63 & 4.26 & 1,641 & 38,547 & $-1,162$ & 0.173 \\
\hline $\mathrm{pH}_{\mathrm{Ox}}$ & 0.92 & 6.98 & 1.77 & 0.749 & 42,241 & 25,005 & 4,276 \\
\hline $\mathrm{S}_{\mathrm{KCl}}(\%)$ & 0.12 & 2.52 & 0.76 & 0.500 & 66,113 & 0.540 & 1,080 \\
\hline$S_{p}(\%)$ & 0.42 & 4.85 & 2.65 & 0.936 & 35,325 & -0.321 & 0.152 \\
\hline $\mathrm{S}_{\mathrm{POS}}(\%$ & 0.02 & 3.67 & 1.89 & 0.689 & 36,444 & 0.035 & -0.304 \\
\hline TPA (mole H/ tonne) & 6.50 & $2,999.50$ & 826.77 & 554,459 & 67,063 & 1,904 & 1,251 \\
\hline TAA (mole $\mathrm{H}^{+} /$tonne) & 0.00 & 120.00 & 19.54 & 26,693 & 136,619 & 2,944 & 1,776 \\
\hline TSA (mole $\mathrm{H}^{+} /$tonne) & 6.50 & $2,905.50$ & 807.23 & 538,645 & 66,727 & 1,973 & 1,275 \\
\hline Pyrite $(\%)$ & 0.03 & 12.97 & 3.60 & 2,405 & 66,727 & 1,973 & 1,275 \\
\hline Total N (\%) & 0.12 & 1.25 & 0.43 & 0.259 & 60,497 & 1,926 & 1,459 \\
\hline $\mathrm{PO}_{4}(\mathrm{ppm})$ & 0.01 & 81.05 & 19.40 & 13,875 & 71,526 & 4,899 & 1,832 \\
\hline Organic matter $(\%$ & 1.04 & 28.60 & 10.31 & 6,432 & 62,362 & 0.798 & 1,143 \\
\hline $\mathrm{Fe}(\mathrm{mg} / \mathrm{L})$ & 211.50 & $4,976.00$ & $4,296.81$ & 705,319 & 16,415 & 12,001 & $-3,044$ \\
\hline $\mathrm{Al}(\mathrm{mg} / \mathrm{L})$ & 120.00 & $1,026.50$ & 387.97 & 140,761 & 36,281 & 2,959 & 1,195 \\
\hline
\end{tabular}

bution. Tabi \& Ogunkunle (2007) obtained a positive value of skewness for $\mathrm{P}$ - available, $\mathrm{Mg}$, and $\mathrm{K}$ soil in $0-0.15 \mathrm{~m}$ soil depth in Nigeria.

Coefficient of variation of soil brackishwater ponds in Luwu Regency varies from the lowest in $\mathrm{pH}_{\mathrm{F}}(5.454 \%$ and the highest in TAA (379.692\% for 0- $0.2 \mathrm{~m}$ soil depth (Table 1 ), while the lowest value of the coefficient of variation is also in $\mathrm{pH}_{\mathrm{F}}(3.889 \%$ and the highest in TAA (136.619\%) for 0.5- $0.7 \mathrm{~m}$ soil depth (Table 2 ). Similar results were reported for brackishwater ponds in Pangkep Regency South Sulawesi Province (Rachmansyah \& Mustafa, 2011). Goh et al. (1998) also reported that coefficient of variation of soil characteristics in Sabah (Malaysia) can exceed $100 \%$ on the same soil series. Beguería et al. (2013) reported that coefficient of variation of soil characteristics exceeds $77 \%$ Coefficient of variation of soil characteristics are of great value, and only reflect conditions at specific locations (Saadi \& Athanasopoulos- Zekkos, 2013). Based on the classification established by Essington (2004), variable classified as having small variability or relatively homogeneous was $\mathrm{pH}_{\mathrm{F}}$; variables classified as having moderate variability were
$\mathrm{pH}_{\mathrm{F}}-\mathrm{pH}_{\mathrm{FOx}}$ and $\mathrm{pH}_{\mathrm{KCl}}$, while other soil quality variables relatively have high variability or relatively heterogeneous for $0-0.2 \mathrm{~m}$ soil depth. In 0.5- $0.7 \mathrm{~m}$ soil depth, variables which have relatively small variability or relatively homogeneous were $\mathrm{pH}_{\mathrm{F}}$ and $\mathrm{pH}_{\mathrm{F}}-\mathrm{pH}_{\mathrm{Fox}}$, variables classified as having moderate variability were $S_{p}$ and $\mathrm{Fe}$, while other soil quality variables have relatively high variability or relatively heterogeneous. This indicate that general soil characteristics of brackishwater ponds in Luwu Regency relatively have high variability or relatively heterogeneous. Essington (2004) stated that soil characteristics have relatively high variability due to location on the landscape and soil depth difference. High variability of soil characteristics in the same soil series has also been reported in Malay Peninsular by Law \&Tan (1977). It also has been reported that the characteristics of brackishwater ponds soil in Indonesia are similar to those in Pekalongan City Central Java Province (Asaad \& Mustafa, 2011) and Pangkep Regency South Sulawesi Province (Rachmansyah \& Mustafa, 2011) which have relatively high variability or relatively heterogeneous. Vertical spatial distribu- 
tion of brackishwater ponds soil in Luwu Regency, can be seen in Tables 1 and 2, while spatial horizontally distribution is shown in Figures 2- 7.

Redox potential describes the condition of the soil which is oxidized or reduced. Redox potential is a quantitative measurement results to inform a diagnostic index of the level of anaerobic or anoxic soil (Patrick \& Delaune, 1977). Table 1 shows that the redox potential of the soil in 0- $0.2 \mathrm{~m}$ soil depth was higher than in 0.5- $0.7 \mathrm{~m}$ soil depth. It can be caused by the drying of brackishwater pond bottom which is usually done by farmers at the time preparation of brackishwater pond, in which the surface of brackishwater ponds soil becomes dry, so that the soil redox potential was higher than the soil beneath the surface. In general, brackishwater ponds soil in Luwu Regency was classified under reduced conditions. This was as a result of soil sampling conducted in brackishwater while in the process of both shrimp and milkfish culture in monoculture or polyculture between milkfish and seaweed and polyculture among milkfish, tilapia, and seaweed, so brackishwater ponds are in waterlogged conditions.

All forms of $\mathrm{pH}$ measured in this research $\left(\mathrm{pH}_{\mathrm{F}}, \mathrm{pH}_{\mathrm{FOX}}, \mathrm{pH}_{\mathrm{KCl}}, \mathrm{pH}_{\mathrm{OX}}\right)$ were showed higher value in the depth of $0-0.2 \mathrm{~m}$ soil depth than in $0.5-0.7 \mathrm{~m}$ soil depth. This was as a result of natural leaching process in a relatively long period of time, causing compounds of soil acidity was decreased on the soil surface. In addition, soil management practices such as the use of lime by farmers is leading to high $\mathrm{pH}_{\mathrm{F}}$ in the surface soil. Pond farmers in brackishwater ponds in Luwu Regency applied agricultural lime up to $250 \mathrm{~kg} / \mathrm{h}$ with an average of 104 $\mathrm{kg} / \mathrm{ha}$ (Mustafa \& Sammut, 2010). Applying lime on soil surface can only give real effect in soil depth of $0.05 \mathrm{~m}$ (Conyers et al., 2003). On the other hand, liming in dyke of brackishwater ponds- affected acid sulfate soil can reach a depth of $0.4 \mathrm{~m}$, as a result of the fracture in dyke so that lime can give real effect to such depths (Mustafa, 2007). At a depth of 0- $0.2 \mathrm{~m}$ soil appeared that the relatively low $\mathrm{pH}$ found in the northern part of Luwu Regency, include East Lamasi, East Walenrang, Bua, and Ponrang Subdistricts (Figures 2 and 3).

$\mathrm{pH}_{\mathrm{F}}-\mathrm{pH}_{\mathrm{FOX}}$ value is often used as one of the variable quality of the soil to determine the potential acidity of the soil. The values of $\mathrm{pH}_{\mathrm{F}^{-}}$ $\mathrm{pH}_{\mathrm{Fox}}$ were ranged between 0.99 and 6.15 (av- erage 4.48) at a depth of $0-0.2 \mathrm{~m}$ and between 2.09 and 6.33 (average 5.04) at a depth of 0.5$0.7 \mathrm{~m}$. It was clear that soil in brackishwater ponds of Luwu was classified as acid sulfate soil. On acid sulfate soil, $\mathrm{pH}_{\mathrm{F}}-\mathrm{pH}_{\mathrm{Fox}}$ can exceed the value of 5 (Mustafa \& Rachmansyah, 2008). It was also clarified the previous description that the degree of acidity in the soil surface was lower than the soil at a depth of $0.5-0.7 \mathrm{~m}$. Figure 2 shows that there have a value of $\mathrm{pH}_{\mathrm{F}}$ $\mathrm{pH}_{\text {Fox }}$ fairly low in brackishwater pond of Luwu which was located in the northern part. Relative spatial distribution similar to $\mathrm{pH}_{\mathrm{F}}-\mathrm{pH}_{\mathrm{FOX}}$ was the spatial distribution of $\mathrm{pH}_{\mathrm{Ox}}$, but in areas high value of $\mathrm{pH}_{\mathrm{F}}-\mathrm{pH}_{\mathrm{FOX}}$ the other wise low $\mathrm{pH}_{\mathrm{Ox}}$. $\mathrm{pH}_{\mathrm{ox}}$ is the $\mathrm{pH}$ of the soil that has been dried and then oxidized with $\mathrm{H}_{2} \mathrm{O}_{2} 30 \%$ (McElnea \& Ahern, 2004b), that describes all potential existing in the soil acidity.

Spatial distribution of organic matter content also has shown the same pattern with $\mathrm{pH}_{\mathrm{F}}-$ $\mathrm{pH}_{\mathrm{Fox}}$. This suggests that the potential for soil acidity in brackishwater ponds of Luwu, apart from pyrite was also derived from organic matter. High organic matter content was derived from mangrove forest conversion to brackishwater ponds. Fallen leave is the largest contributor of organic matter in sediments of mangrove forests (Koch, 2005). Decomposition of organic matter can produce humic acids that lead to lower soil pH. Another possibility of the high acidity of the soil from mangrove forest because of the high tannin content of Rhizophora sp., Bruguiera sp., Ceriopstagal, Xylocarpus granatum, and Nypa fruticans which can cause more acid soil (Mustafa, 2007). Thus, land cover/land use such as the mangrove forest may be the cause of the variation of soil organic matter content. Spatial distribution of organic matter content depends on land cover/land use, and more specifically different between forest land and land used for agricultural cultivation (Martin et al., 2011). It has been reported that land cover/land use in coastal area of Luwu are mangrove forest, brackishwater pond, paddy fields, shrub, dry forests, uni irrigated fields, and settlements. Land cover/land use is one factor that causes the variation of soil characteristics (Ersahin, 2003).

Results of other variables that describe the measurement of soil acidity were $S_{K C l}, S_{p}, S_{p O S}$, TPA, and TSA, and the variables showed the same relative spatial distribution of soil acidity with variables that have been previously de- 
Spatial distribution of some chemical characteristics ... (Erna Ratnawati)
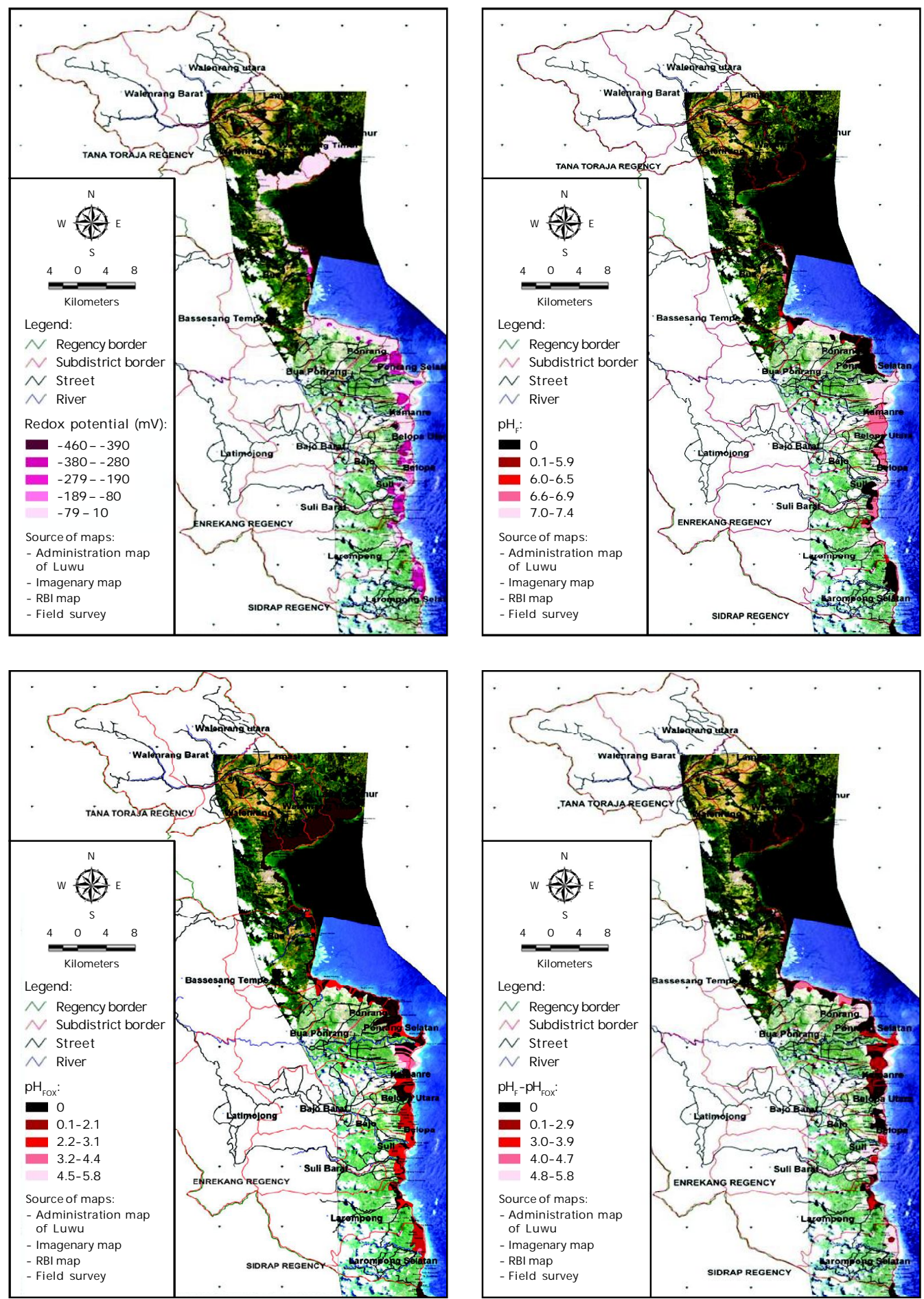

Figure 2. Spatial distribution map of redox potential (top left), $\mathrm{pH}_{\mathrm{F}}$ (top right), $\mathrm{pH}_{\mathrm{Fox}}$ (bottom left), and $\mathrm{pH}_{\mathrm{F}}-\mathrm{pH}_{\mathrm{FOx}}$ (bottom right) of brackishwater ponds soil in $0-0.2 \mathrm{~m}$ soil depth in coastal area of Luwu Regency South Sulawesi Province 

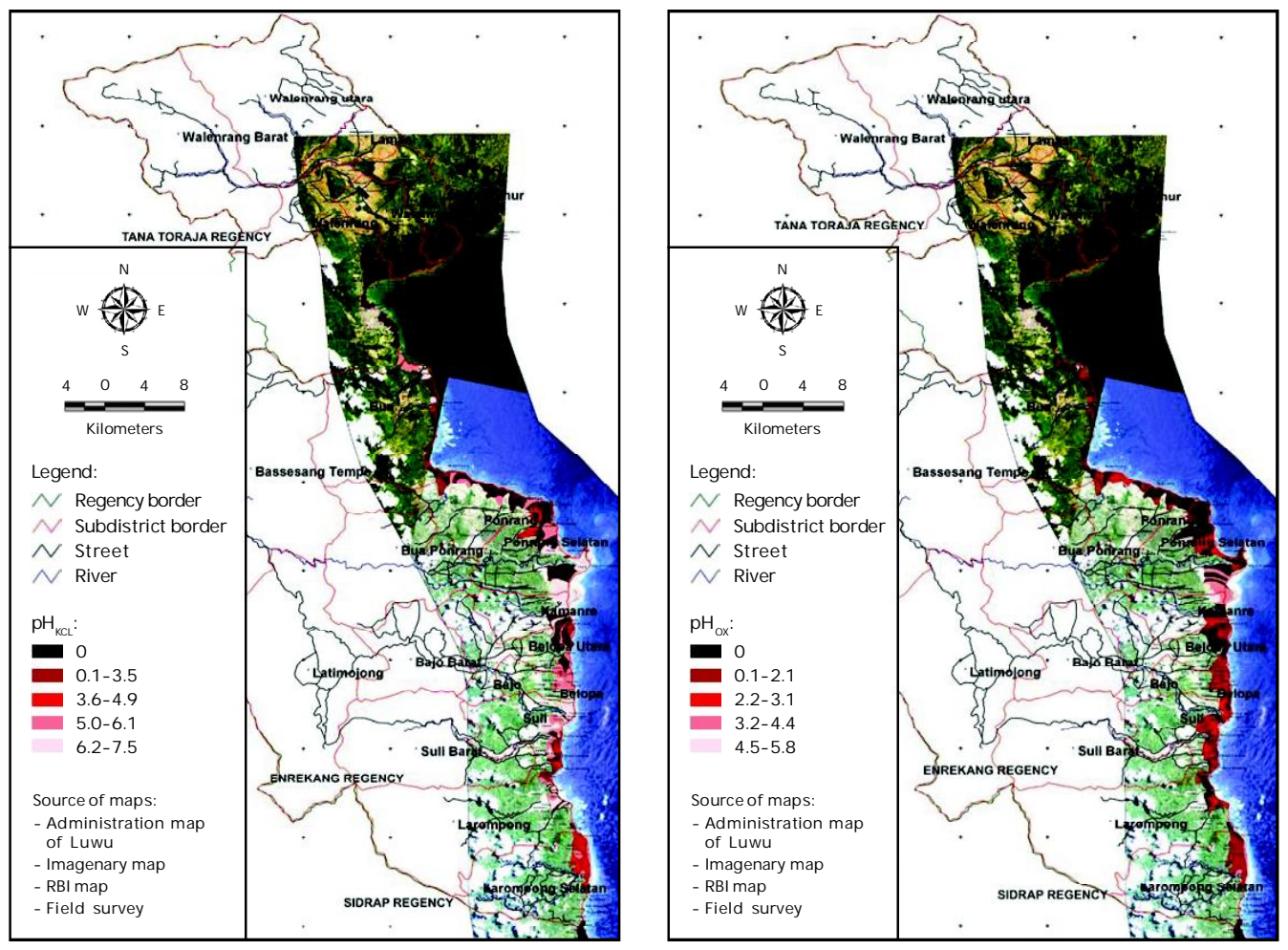

Figure 3. Spatial distribution map of $\mathrm{pH}_{\mathrm{KCl}}$ (left) and $\mathrm{pH}_{\mathrm{Ox}}$ (right) of brackishwater ponds soil in 0- $0.2 \mathrm{~m}$ of depth in coastal area of Luwu Regency South Sulawesi Province

scribed, namely $\mathrm{pH}_{\mathrm{Ox}}$. Figures 4 and 5 show that the value $\mathrm{S}_{\mathrm{KCl}}, \mathrm{S}_{\mathrm{p}}, \mathrm{S}_{\mathrm{POS}}$, TPA, and TSA were found on soil surface of brackishwater ponds mainly located in the northern part of Luwu Regency, namely: in East Lamasi, East Walenrang, Bua, and Ponrang Subdistricts. McElnea et al. (2002a; 2002b) stated that the acid sulfate soil, especially organic matter content is low, then the TSA correlates well with $\mathrm{S}_{\text {pos. }}$ TSA also has a linear relationship with the content of pyrite on acid sulfate soil (Rachmansyah \& Mustafa, 2011). Variables that describe the quality of the soil acidity were generally lower concentration at a depth of 0$0.2 \mathrm{~m}$ than $0.5-0.7 \mathrm{~m}$. It has been reported by Mustafa (2007) that $\mathrm{S}_{\mathrm{pOS}}$ pond bottom soil decreased from $2.1300 \%$ to $1.8587 \%$ or $0.2713 \%$ reduced after the pond bottom soil remediated three times for 72 days.

Pyrite $\left(\mathrm{FeS}_{2}\right)$ is the main characteristic of acid sulfate soil. Relatively low content of pyrite was found in the northern part of Luwu Regency: East Lamasi, East Walenrang, Bua, and Ponrang Subdistrict (Figure 5). Factors that in- fluence the formation of pyrite are the amount of organic matter, sediment temperature, supply $\mathrm{SO}_{4}$ and bicarbonate, anaerobic atmosphere, and content of Fe (Dent, 1986). The low content of pyrite in the north of Luwu was caused by lower organic matter content (Figure 6). Organic matter is a source of carbon for the bacteria in the formation of pyrite. Ersahin (2003) stated that variations of soil characteristics in addition to the result of the factors and processes of land use, as well as a result of the factors or pedogenesis processes.

Western and northern parts Luwu consist of Lamasi volcanic. Existence at the height elevation of Lamasi volcanic can determine the characteristics of sedimentary material that is based on the source rock. Volcanic rocks of Lamasi transported through the river and deposited in the coastal area. The upper of Lamasi River consists of a Lamasi volcanic. Lava light gray color containing pyrite has been found by Ratman \&Atmawinata (1993) in Lamasi volcanic. Breccia in Lamasi volcanic, in some places formed hydrothermally altered pyrite, gold, 
Spatial distribution of some chemical characteristics ... (Erna Ratnawati)
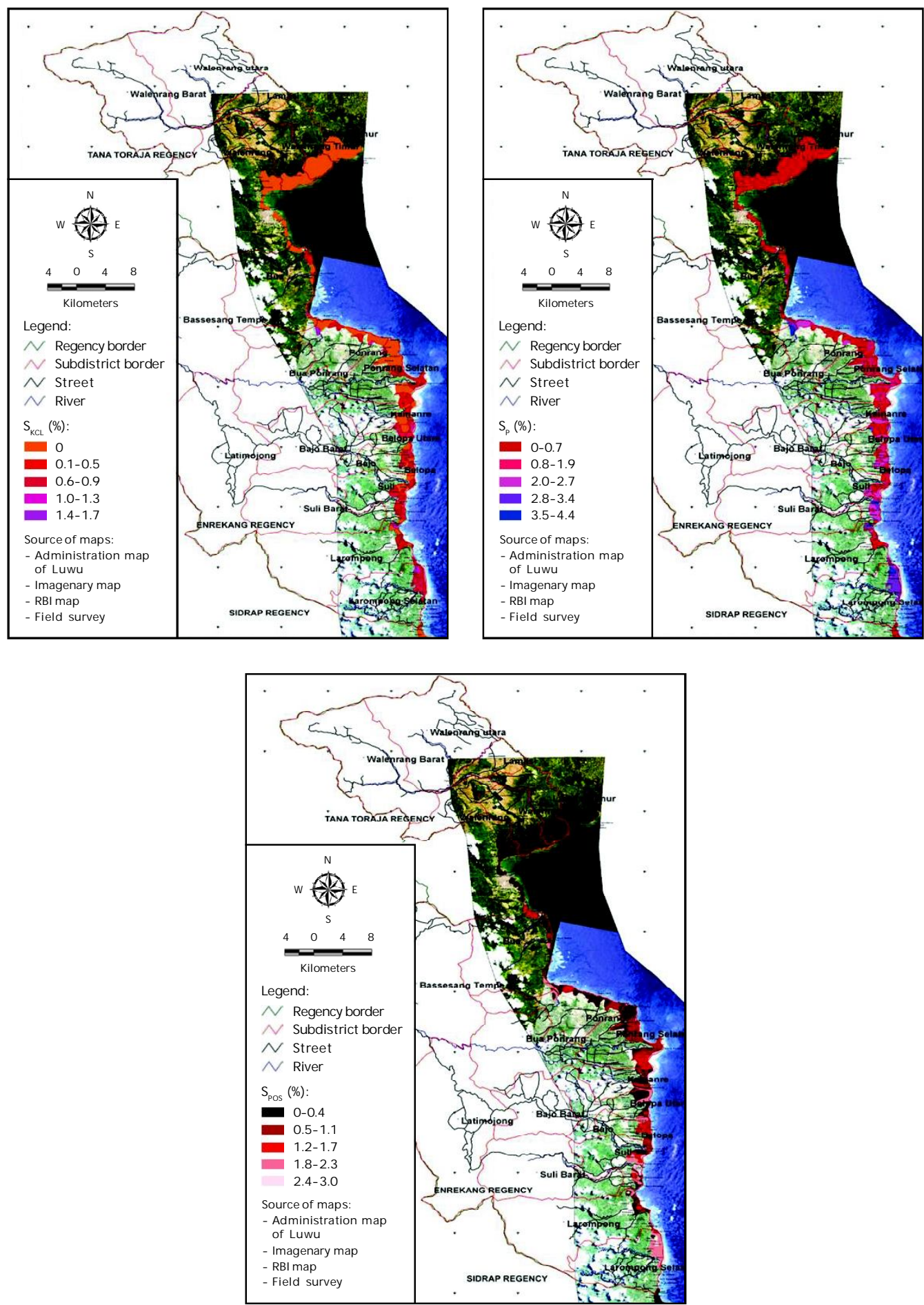

Figure 4. Spatial distribution map of $\mathrm{S}_{\mathrm{KCI}}$ (top left), $\mathrm{S}_{\mathrm{p}}$ (top right) and $\mathrm{S}_{\mathrm{POS}}$ (bottom) of brackishwater ponds soil in 0- 0.2 m of depth in coastal area of Luwu Regency South Sulawesi Province 

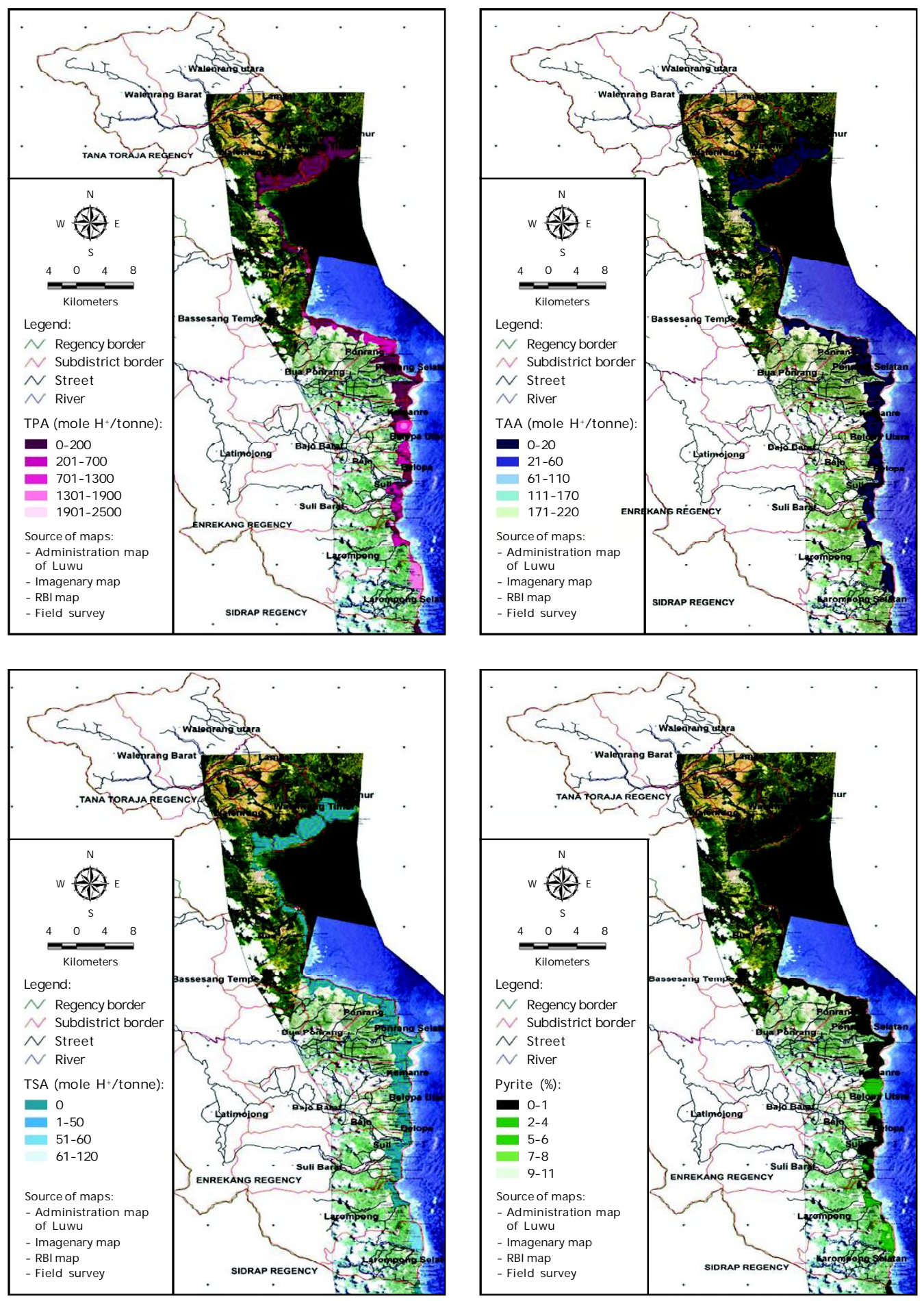

Figure 5. Spatial distribution map of TPA (top left), TAA (top right), TSA (bottom left), and pyrite (bottom right) of brackishwater ponds soil in 0- $0.2 \mathrm{~m}$ of depth in coastal area of Luwu Regency South Sulawesi Province 
Spatial distribution of some chemical characteristics ... (Erna Ratnawati)
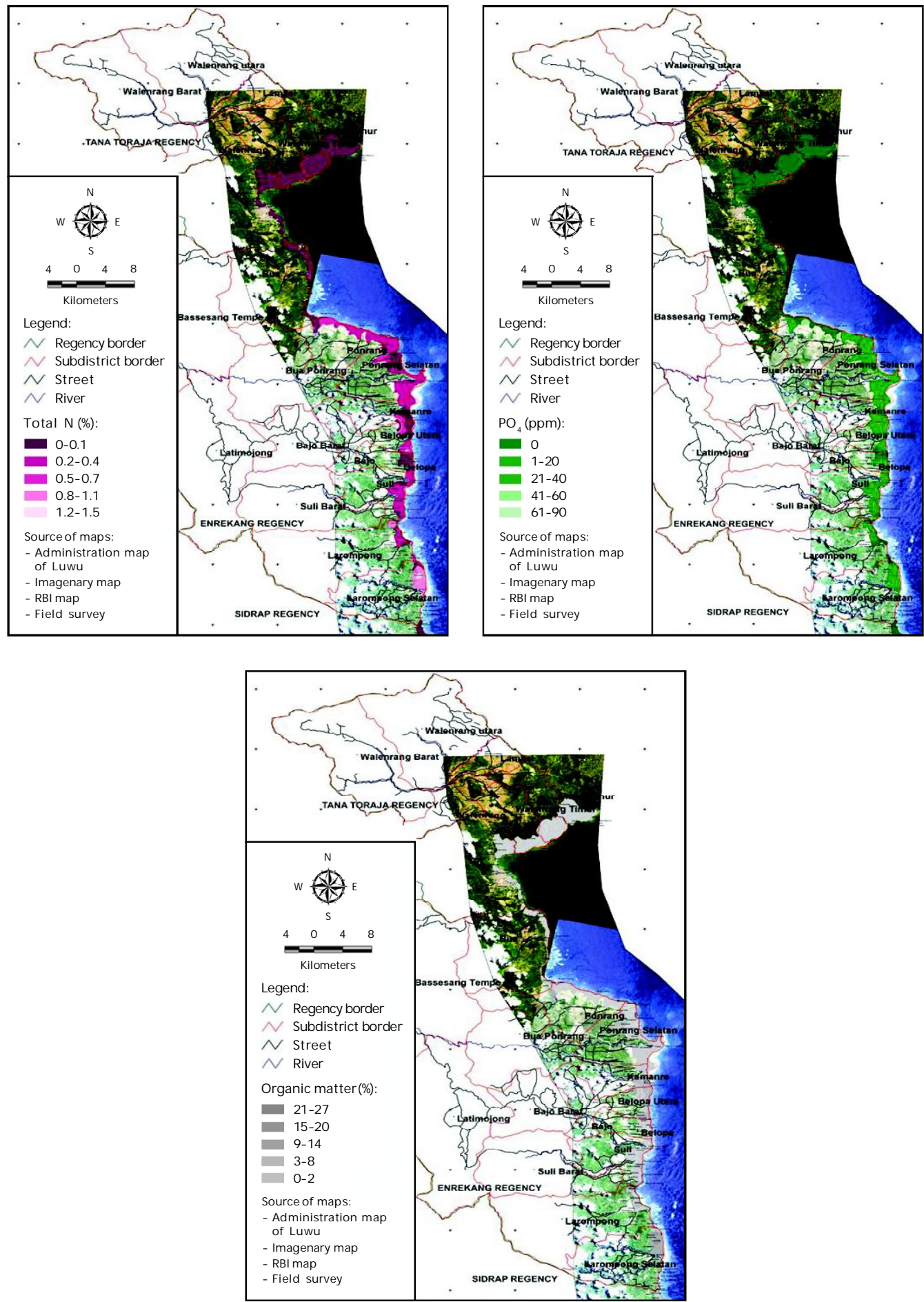

Figure 6. Spatial distribution map of total $\mathrm{N}$ (top left), $\mathrm{PO}_{4}$ (top right) and organic matter (bottom) of brackishwater ponds soil in 0- 0.2 m of depth in coastal area of Luwu Regency South Sulawesi Province 
and silver deposits (Simandjuntak et al., 1991 in Ernowo \& Pardiarto, 2011). According to Ratman \& Atmawinata (1993), breccia from Lamasi volcanic containing quartz with sulfide minerals (mainly pyrite) and copper. Tuff in Lamasi volcanic also containing pyrite and copper (Ratman \&Atmawinata, 1993). However, pyrite from Lamasi volcanic was not associated with pyrite present in acid sulfate soil in coastal area. High content of soil organic matter was found in the southern of Luwu Regency. Soil in the southern part of Luwu can also be classified as peat soil because organic matter content higher than $20 \%$ Peat soil is soil that contains organic material more than $20 \%$ (when the soil is not containing clay) or more than $30 \%$ (when the soil is containing clay more than or equal to $60 \%$ (Soil Survey Staff, 2001).

Spatial distribution of nutrient content of brackishwater pond soil in Luwu is shown in Figures 6 and 7. It illustrated that the organic matter content, total $\mathrm{N}, \mathrm{Fe}$, and $\mathrm{Al}$ have a relatively similar distribution pattern. Organic mat-

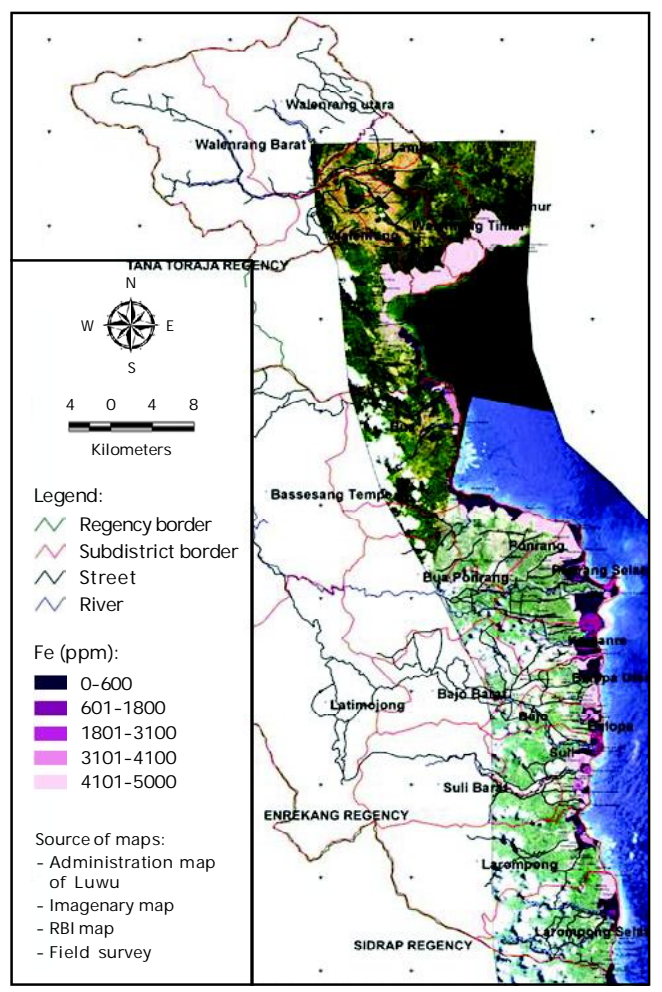

ter, instead as a carbon source, also a source of nitrogen (Boyd, 2008), that was having a great influence on the chemical and physical soil fertility (Chen et al., 2011). According to Abuduwaili et al. (2012), Choudhury et al. (2013), and Zhang et al. (2013), the distribution of nutrient content of soil in natural systems is mainly influenced by topography, climate, and biological activity of natural soil fertility. High content of $\mathrm{Fe}$ and $\mathrm{Al}$ in the area of high organic matter content as a result of the low $\mathrm{pH}$ in the area that causes the solubility of both the toxic elements are high. The content of $\mathrm{Al}$ in acid sulfate soil increases at lower $\mathrm{pH}$, i.e. $\mathrm{pH}$ 4.0-4.5 (Dent, 1986). In addition, the content of $\mathrm{Al}$ in acid sulfate soil associated with pyrite oxidation. The atmosphere is very acid accelerate alumino- silicate mineral weathering due to the destruction of 2:2 layer type minerals (such as montmorillonite) into a 1:1 type minerals (kaolinite) to liberate and more dissolving Al (Pons, 1973). Contents of Fe and Al were higher in the subdistricts of North Belopa, Belopa, Suli, Larompong, and South

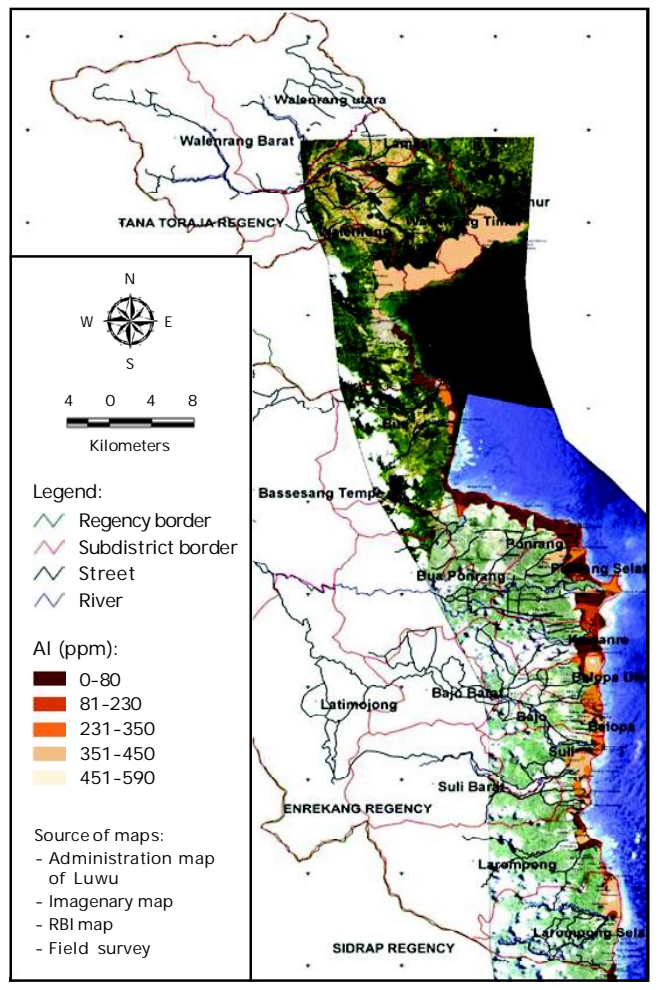

Figure 7. Spatial distribution map of iron (left) and aluminium (right) of brackishwater ponds soil in 0- 0.2 m of depth in coastal area of Luwu Regency South Sulawesi Province 
Larompong, those can cause relatively lower content of $\mathrm{PO}_{4}$ (phosphate). This was as a result of $\mathrm{Fe}$ and $\mathrm{Al}$ soil that can cause $\mathrm{PO}_{4}$ become unavailable. At low soil $\mathrm{pH}, \mathrm{PO}_{4}$ bound strongly by $\mathrm{Fe}$ and $\mathrm{Al}$ in the form of insoluble $\mathrm{FePO}_{4}$ or $\mathrm{AlPO}_{4}$ (Mustafa \& Sammut, 2007; Moriarty, 2010). Figures 5 and 6 show that the low $\mathrm{PO}_{4}$ content found in area that contain high $\mathrm{Fe}$ and $\mathrm{Al}$.

\section{CONCLUSIONS AND RECOMMENDATIONS}

Brackishwater pond soil in coastal area of Luwu Regency South Sulawesi Province, Indonesia was acid sulfate soil and acid sulfate soil associated with peat soils. In general, soil chemical characteristics of brackishwater pond has a high variability or relatively heterogeneous with coefficient of variation in excess of $36 \%$ Chemical characteristics of the soil that indicates oil acidity has a spatial distribution pattern relatively similar. More over the chemical characteristics of the soil that indicate nutrient content of the soil also has a relatively similar spatial distribution pattern. A low degree of soil acidity and conversely a high content of $\mathrm{PO}_{4}$ generally found in East Lamasi, East Walenrang, Bua, and Ponrang Subdistricts. It is recommended that soil management in brackishwater ponds of Luwu Regency could be based on soil chemical characteristics which could improve the production through minimizing the input, increasing carrying capacity, and avoiding environmental degradation.

\section{ACKNOWLEDMENT}

Special acknowledgment for Muhammad Arnol and Darsono for their support in the measurement and soil sampling in the field as well as Rosiana Sabang, Kamariah, and Rahmiyah for their assistance in the analysis of soil quality in the laboratory.

\section{REFERENCES}

Aberegg, I., Egli, M., Sartori, G., \& Purves, R. 2009. Modelling spatial distribution of soil types and characteristics in a high Alpine valley (Val di Sole, Trentino, Italy). Studi Trentini di Scienze Natur al, 85: 39- 50.

Abuduwaili, J., Tang, Y., Abulimiti, M., Liu, D.W., \& Ma, L. 2012. Spatial distribution of soil moisture, salinity and organic matter in Manas River watershed, Xinjiang, China. Journal of Arid Land, 4(4): 441- 449.

Ahern, C.R. \& Blunden, B. 1998. Designing a soil sampling and analysis program. In Ahern, C.R., Blunden, B., \&Stone, Y. (Eds.), Acid sulfate soils laboratory methods guidelines. Acid Sulfate Soil Management Advisory Committee, Wollongbar. NSW, p. 2.12.6.

Ahern, C.R. \& McElnea, A.E. 2004. Calculated sulfur parameters. In Acid sulfate soils laboratory methods guidelines. Queensland Department of Natural Resources, Mines and Energy. Indooroopilly. Queensland, p. B11-1-B11-2.

Ahern, C.R., McElnea, A., \& Baker, D.E. 1998a. Peroxide oxidation combined acidity and sulfate. In Ahern, C.R., Blunden, B., \& Stone, Y. (Eds.), Acid sulfate soils laboratory methods guidelines. Acid Sulfate Soil Management Advisory Committee, Wollongbar. NSW, p. 4.1-4.17.

Ahern, C.R., McElnea, A., \& Baker, D.E. 1998b. Total oxidisable sulfur. In Ahern, C.R., Blunden, B., \&Stone, Y. (Eds.), Acid Sulfate Soils Laboratory Methods Guidelines. Acid Sulfate Soil Management Advisory Committee, Wollongbar. NSW, p. 5.1- 5.7.

Ahern, C.R. \& Rayment, G.E. 1998. Codes for acid sulfate soils analytical methods. In Ahern, C.R., Blunden, B., \& Stone, Y. (Eds.), Acid Sulfate Soils Laboratory Methods Guidelines. Acid Sulfate Soil Management Advisory Committee, Wollongbar. NSW, p. 3.1-3.5.

Akbarzadeh, A. \& Taghizadeh-Mehrjardi, R. 2010. Spatial distribution of some soil properties, using geostatistical methods in Khezrabad Region (Yazd) of Iran. Pro Environment, 3: 100- 109.

Anonymous. 2009. Fisheries Statistic Report of South Sulawesi, 2008. Fisheries and Marine Office of South Sulawesi Province. Makassar, $243 \mathrm{pp}$.

Anuar, A.R., Goh, K.J., Heoh, T.B., \&Ahmed, O.H. 2008. Spatial variability of soil inorganic $N$ in a mature oil palm plantation in Sabah, Malaysia. American Journal of Applied Sciences, 5(9): 1,239- 1,246.

Asaad, A.I. \& Mustafa, A. 2011. Spatial distribution of brackishwater pond soil characteristics in Pekalongan City Central Java Province. Indonesian Aquaculture Journal, 6(1): 91- 105.

Barthold, F.K., Wiesmeier, M., Breuer, L., Frede, H.- G. Wu, J., \& Blank, F.B. 2013. Land use and climate control the spatial distribution of soil types in the grasslands of Inner 
Mongolia. Journal of Arid Environments, 88: 194- 205.

Beguería, S., Spanu, V., Navas, A., Machín, J., \& Angulo- Martínez, M. 2013 Modelling the spatial distribution of soil properties by generalized least squares regression: Toward a general theory of spatial variates. Journal of Soil and Water Conservation, 68(3): 172- 184.

Boyd, C.E. 2008. Pond bottom soil analyses. Global Aquaculture Advocate, September/ October: p. 91- 92.

Chen, L.D., Qi, X., \&Zhang, X.Y. 2011. Effect of agricultural land use changes on soil nutrient use efficiency in an agricultural area, Beijing, China. Chinese Geographical Science, 21(4): 392- 402.

Choudhury, B.U, Mohapatra, K.P., Das, A., Das, P.T., Nongkhlaw, L., Fiyaz, R.A. Ngachan, S.V., Hazarika, S., Rajkhowa, D.J., \& Munda, G.C. 2013. Spatial variability in distribution of organic carbon stocks in the soils of North East India. Current Science, 104(5): 604- 614.

Conyers, M.K., Heenan, D.P., McGhie, W.J., \& Poile, G.P. 2003. Amelioration of acidity with time by limestone under contrasting tillage. Soil \& Tillage Research, 72: 85- 94.

Dent, D. 1986. Acid Sulphate Soils: A Baseline for Research and Development. ILRI Publication 39. International Institute for Land Reclamation and Improvement. Wageningen, $204 \mathrm{pp}$.

Dong, X.W., Zhang, X.K., Bao, X.L., \& Wang, J.K. 2009. Spatial distribution of soil nutrients after the establishment of sand-fixing shrubs on sand dune. Plant Soil Environment, 55(7): 288- 294.

Ernowo \& Pardiarto, B. 2011. Geological aspects in the preparation of metallic mineral mining areas. Buletin Sumber Daya Geologi, 6(2): 1- 8.

Ersahin, S. 2003. Comparing ordinary kriging and cokriging to estimate infiltration rate. Soil Science, 67: 1,848- 1,855.

Essington, M.E. 2004. Soil and Water Chemistry: An Integrative Approach. CRC Press. Boca Raton, 534 pp.

Giap, D.H., Yi, Y., \& Yakupitiyage, A. 2005. GIS for land evaluation for shrimp farming in Haiphong of Vietnam. Ocean \& Coastal Management, 48: 51- 63.

Goh, K.J., Kee, K.K., \& Chew, P.S. 1998. Soil fertility status of some common soils in Sabah,
Malaysia. In Aziz, B. \& Husni, A.M.S. (Eds.), Proceedings of the Soil Science Conference of Malaysia. Malaysian Society of Soil Society. Kuala Lumpur, p. 1- 16.

Hazelton, P. \& Murphy, B. 2009. Interpreting Soil Test Results: What do All the Numbers Mean? CSIRO Publishing. Collingwood, 152 pp.

Huang, X., Skidmore, E.L., \& Tibke, G. 2001. Spatial variability of soil properties along a transect of CRP and continuously cropped land. In Stott, D.E., Mohtar, R. E., \& Steinhardt, G.C. (Eds.), Sustaining the Global Farm. Selected papers from $10^{\text {th }}$ International Soil Conservation Organization Meeting held May 24- 29, 1999 at Purdue University and the USDA-ARS National Soil Erosion Research Laboratory. p. 641- 647.

Karthik, M., Suri, J., Saharan, N., \& Biradar, R.S. 2005. Brackish water aquaculture site selection in Palghar Taluk, Thane district of Maharashtra, India, using the techniques of remote sensing and geographical information system. Aquacultural Engineering, 32: 285- 302.

Ministry of Marine Affairs and Fisheries (MMAF). 2011. Marine and Fisheries in Figures 2011. Centre of Data Statistics and Information. Jakarta, 120 pp.

Koch, B.P. 2005. Organic matter pathways in a mangrove system in Northen Brazil- Chemical tracers of major sources under the influence of sedimentation and biological degradation. Center for Tropical Marine Ecology. Bremen, 109 pp.

Law, W.M. \&Tan, M.M. 1977. Chemical properties of some Peninsular Malaysian soil series. Proceedings of Chemistry and Fertility of Tropical Soils. Malaysian Society of Soil Society. Kuala Lumpur, p. 180-191.

Lin, C., Wood, W., Heskins, P., Ryffel, T., \& Lin, J. 2004. Controls on water acidification and de- oxygenation in an estuarine waterway, eastern Australia. Estuarine Coastal and Shelf Science, 61: 55- 63.

Lin, Y.P. 2008. Simulating spatial distributions, variability and uncertainty of soil arsenic by geostatistical simulations in geographic information systems. Open Environmental Sciences, 2: 26- 33.

Lin, Y.P., Chang, T.K., \&Teng, T.P. 2001. Characterization of soil lead by comparing sequential Gaussian simulation, simulated annealing simulation and kriging methods. Environmental Geology, 41: 189- 199. 
Liu, D., Wang, Z., Zhang, B., Song, K., Li, X., Li, J., Li, F., \&Duan, H. 2006. Spatial distribution of soil organic carbon and analysis of related factors in croplands of the black soil region, Northeast China. Agriculture, Ecosystems and Envir onment, 113: 73-81.

Madyaka, M. 2008. Spatial modelling and prediction of soil salinization using salt mod in a GIS environment. Master of Science Thesis. International Institute for Geo- Information Science and Earth Observation. Enschede, 128 pp.

Martin, M.P., Wattenbach, M., Smith, P., Meersmans, J., Jolivet, C., Boulonne, L., \& Arrouays, D. 2011. Spatial distribution of soil organic carbon stocks in France. Biogeosciences, 8: 1,053- 1,065.

McElnea, A.E. \&Ahern, C.R. 2004a. KCl extractable $\mathrm{pH}\left(\mathrm{pH}_{\mathrm{KCl}}\right)$ and titratable actual acidity (TAA). In Acid sulfate soils laboratory methods guidelines. Queensland Department of Natural Resources, Mines and Energy, Indooroopilly. Queensland, p. B2- 1- B2- 3.

McElnea, A.E. \& Ahern, C.R. 2004b. Peroxide $\mathrm{pH}\left(\mathrm{pH}_{\mathrm{ox}}\right)$, titratable peroxide acidity (TPA) and excess acid neutralising capacity $\left(\mathrm{ANC}_{\mathrm{E}}\right.$ ). In Acid sulfate soils laboratory methods guidelines. Queensland Department of Natural Resources, Mines and Energy, Indooroopilly. Queensland, p. B3- 1- B3- 7.

McElnea, A.E. \&Ahern, C.R. 2004c. Sulfur- peroxide oxidation method. In Acid sulfate soils laboratory methods guidelines. Queensland Department of Natural Resources, Mines and Energy, Indooroopilly. Queensland, p. B7- 1- B7- 2.

McElnea, A.E. \& Ahern, C.R. 2004d. Sulfur 1M $\mathrm{KCl}$ extraction $\left(\mathrm{S}_{\mathrm{KCl}}\right)$. In Acid sulfate soils laboratory methods guidelines. Queensland Department of Natural Resources, Mines and Energy, Indooroopilly. Queensland, p. B8- 1- B8- 2.

McElnea, A.E., Ahern, C.R., \& Menzies, N.W. 2002a. Improvements to peroxide oxidation methods for analysing sulfur in acid sulfate soils. Australian Journal of Soil Research, 40: 1,115-1,132.

McElnea, A.E., Ahern, C.R., \& Menzies, N.W. $2002 \mathrm{~b}$. The measurement of actual acidity in acid sulfate soils and the determination of sulfidic acidity in suspension after peroxide oxidation. Australian Journal of Soil Research, 40: 1,133- 1,157.

Menon, R.G. 1973. Soil and Water Analysis: A Laboratory Manual for the Analysis of Soil and Water. Project Survey O.K.T. Sumatera Selatan, Palembang. 190 pp.

Moriarty, D.J.W. 2010. Sulphide and phosphate problems in shrimp ponds. AQUA Culture Asia Pacific, 6(5): 42- 45.

Mulla, D.J. \& McBratney, A.B. 1999. Soil spatial variability. In Sumner, M.E. (Ed.), Handbook of soil science. CRC Press. Boca Raton, $p$. A321-A352.

Mustafa, A. 2007. Improving acid sulfate soils for brackish water ponds in South Sulawesi, Indonesia. Ph.D. Thesis. The University of New South Wales. Sydney, 418 pp.

Mustafa, A. \& Rachmansyah. 2008. Policy in the utilization of acid sulfate soil for aquaculture. In Sudradjat, A., Rusastra, I W., \& Budiharsono, S. (Eds.), Aquaculture Development Policy Analysis. Centre Research Institute for Aquaculture. Jakarta, p. 1- 11.

Mustafa, A., Radiarta, I N., \& Rachmansyah. 2011. Profile sand land suitability for aquaculture supporting minapolitan. Sudradjat, A. (Ed.), Center for Aquaculture Research and Development. Jakarta, $91 \mathrm{pp}$.

Mustafa, A. \& Sammut, J. 2007. Effect of different remediation techniques and dosages of phosphorus fertilizer on soil quality and klekap production in acid sulfate soil- affected aquaculture ponds. Indonesian Aquaculture Journal, 2(2): 141- 157.

Mustafa, A. \& Sammut, J. 2010. Dominant factors effecting seaweed (Gracilaria ver rucosa) production in acid sulfate soils- affected ponds of Luwu Regency, Indonesia. Indonesian Aquaculture Journal, 5(2): 147- 162.

PanGonzalez, A., Vieira, S.R., \& Taboada, C.M.T. 2000 . The effect of cultivation on the spatial variability of selected properties of an umbric horizon. Geoderma, 97(3-4): 273292.

Patrick, Jr. W.H. \& Delaune, R.D. 1977. Chemical and biological redox systems affecting nutrient availability in the coastal wetlands. Geoscience and Man, 18: 131- 137.

Pons, L.J. 1973. Outline of genesis, characteristics, classification and improvement of acid sulphate soil. In Dost, H. (Ed.), Acid sulphate soils. ILRI Publication 18. International Institutefor Land Reclamation and Improvement. Wageningen, p. 1-27.

Rachmansyah \& Mustafa, A. 2011. Spasial distribution of brackish water ponds soil characteristics in Pangkep Regency South Sulawesi Province. J. Ris. Akuakultur, 6(3): 479- 493. 
Ratman, N. \& Atmawinata, S. 1993. Geology of the Mamuju Quadrangle, Sulawesi. Geological Research and Development Centre. Bandung, $26 \mathrm{pp}$.

Robinson, T.P. \& Metternicht, G. 2006. Testing the performance of spatial interpolation techniques for mapping soil properties. Computer and Electronics in Agriculture, 50: 97- 108.

Saadi, M. \&Athanasopoulos- Zekkos, A. 2013. A framework for assessing spatial distribution of soil properties in levee systems based on underlying geology and river morphology. Journal of Geography and Geology, 5(3): 22- 42.

Salam, M.A., Ross, L.G., \& Beveridge, C.M.M. 2003. A comparison of development opportunities for crab and shrimp aquaculture in Southwestern Bangladesh, using GIS modeling. Aquaculture, 220: 477- 494.

Sammut, J. 1999. Amelioration and management of shrimp ponds in acid sulfate soils: key researchable issues. In Smith, P.T. (Ed.), Towards sustainable shrimp culture in Thailand and the Region. ACIAR Proceedings No. 90. Australian Centre for International Agricultural Research. Canberra, p. 102- 106.

Sammut, J. \&Lines- Kelly, R. 2000. An introduction to acid sulfate soils. Natural Heritage Trust. Canberra, $27 \mathrm{pp}$.

Schaetzl, R.J. \&Anderson, S. 2005. Soils: Genesis and geomorphology. Cambridge University Press. Cambridge, 817 pp.

Soil Survey Staff. 2001. Soil taxonomy, a basic system of soil classification for making and interpreting soil survey. United State Department of Agriculture. Washington D.C., $734 \mathrm{pp}$.

Sokal, R.R. \& Rohlf, F.J. 1981. Biometry: The principles and practice of statistics in biological research. $2^{\text {nd }}$ edition. W.H. Freeman and Co. New York, 859 pp.
Sulaeman, Suparto, \& Eviati. 2005. Technical guidelines for chemical analysis of soil, plant, water, and fertilizer. Prasetyo, B.H., Santoso, D., \& Widowati, L.R. (Eds.), Soil Research Institute. Bogor, $136 \mathrm{pp}$.

Tabi, F.O. \&Ogunkunle, A.O. 2007. Spatial variation of some soil physico- chemical properties of an Alfisol in Southwestern Nigeria. Nigerian Journal of Soil and Environmental Research, 7: 82- 91.

Treece, G.D. 2000. Site selection. In Stickney, R.R. (Ed.), Encyclopedia of aquaculture. John Wiley \& Sons, Inc. New York, p. 869- 879.

Tuzinsky, L. 1990. The regime of moisture and usable water supplies in the soil under forest ecosystems, (in Slovak). Scientific Works of For est Research Institute in Zvolen, 39: 95- 111.

Yu, P., Xu, H., Qiao, M., Zhang, Q., An, H., \& Fu, J. 2011. Spatial distribution pattern changes of oasis soil types in Manasi River Basin, arid Northwestern China. Catena, 87(2): 253- 259.

Zare- Mehrjardi, M., Taghizadeh- Mehrjardi, R., \& Akbarzadeh, A. 2010. Evaluation of geostatistical techniques for mapping spatial distribution of soil $\mathrm{pH}$, salinity and plant cover affected by environmental factors in Southern Iran. Notulae Scientia Biologicae, 2(4): 92- 103.

Zhang, S., Zhang, X., Liu, X., Liu, W., \& Liu, Z. 2013. Spatial distribution of soil nutrient at depth in black soil of Northeast China: a case study of soil available potassium. Nutrient Cycling in Agroecosystems, 95: 319-331.

Zuo, X.A., Zhao, H.L., Zhao, X.Y., Zhang, T.H., Guo, Y.R., Wang, S.K., \& Sam, D. 2008. Spatial pattern and heterogeneity of soil properties in sand dunes under grazing and restoration in Horqin Sandy Land, Northern China. Soil \& Tillage Research, 99: 202212. 